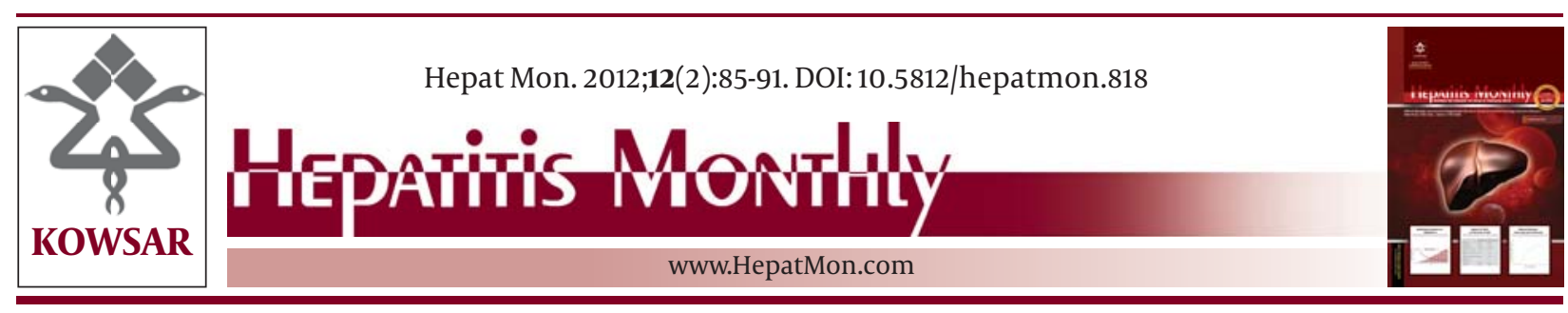

\title{
Hepatitis C Virus Cryoglobulinemia and Non-Hodgkin Lymphoma
}

\author{
Zohreh Jadali ${ }^{*}$ \\ ${ }^{1}$ Department of Immunology, School of Public Health, Tehran University of Medical Sciences, Tehran, IR Iran
}

\begin{tabular}{l}
\hline A R T I C L E I N F O \\
\hline Article type: \\
Review Article \\
\hline Article history: \\
Received:18 Dec 2011 \\
Revised: 05 Jan 2012 \\
Accepted: 21 Jan 2012 \\
\hline
\end{tabular}

Keywords:

Hepatitis C Virus

Cryoglobulinemia

Non-Hodgkin Lymphoma

\begin{abstract}
A B S T R A C T
Context: On the strength of epidemiological data,biological studies, and clinical findings, hepatitis $C$ virus appears to be involved in the pathogenesis of a proportion of patients with non-Hodgkin lymphoma and cryoglobulinemia.

Objectives: The aim of this paper is to review the published literature focused on the current knowledge concerning hepatitis $\mathrm{C}$ virus and its potential role in the production of non-Hodgkin lymphoma and cryoglobulinemia in susceptible individuals.

Evidence Acquisition: In this review, databases such as pubMed, embase, ISI, and Iranian databases including Iranmedex, and SID were searched.

Results: The results of this review indicate that HCV infection may be a likely cause of various B cell dysregulation disorders such as non-Hodgkin lymphoma and cryoglobulinemia.

Conclusion: Based on current findings, it has been hypothesized that NHL and cryoglobulinemia in HCV infection may have an immune-mediated pathogenesis. In HCV infected patients, we showed an elevated risk of these two diseases. These finding suggested a possible role for chronic hepatitis $\mathrm{C}$ in the pathogenesis of NHL and cryoglobulinemia.
\end{abstract}

Copyright @ 2012 Kowsar M. P. Co. All rights reserved.

Implication for health policy/practice/research/medical education:

This article elucidates the importance and pathogenic mechanisms of HCV-related B cell dysregulation such as cryoglobulinemia and NHL. Infectious diseases specialists, hematologists, oncologist and virologists should be aware about this important complication when they manage a patients with HCV infection.

Please cite this paper as:

Jadali Z. Hepatitis C Virus Cryoglobulinemia and Non-Hodgkin Lymphoma. Hepat Mon. 2012;12(2):85-91. DOI:10.5812/hepatmon.818

\section{Context}

Hepatitis C virus (HCV) appears to be the virus that is usually associated with profound alterations in the host immune system, resulting in immunological abnormalities and some autoimmune disease (1-3). It has been proposed that HCV infects and replicates in not only hepatocytes but also immune cells, such as B cells. HCV infection of B cells is the possible cause of B cell dysregulation diseases and conditions, including mixed cryoglobulinemia (MC), rheumatoid factor (RF) production, and B cell lymphoproliferative disorders that may progress to non-Hodgkin lymphoma (NHL) (4). Interestingly,

\footnotetext{
* Corresponding author: Zohreh Jadali, Department of Immunology, School of Public Health, Tehran University of Medical Sciences, 141556446, Tehran, IR Iran. Tel: +98-216462268, Fax:+98-216462267,

E-mail: zjadali@razi.tums.ac.ir and zjadali@yahoo.co.uk

DOI:10.5812/hepatmon.818

Copyright $\odot 2012$ Kowsar M.P.Co. All rights reserved.
}

some patients develop low-grade lymphoma, composed of B cells that are immunophenotypically identical to the expanded B cells that are observed in cryoglobulinemia (5). Most of the extrahepatic manifestations (EHMs) of HCV infection are associated with autoimmune or lymphoproliferative states and are thought to be immunemediated. Patients with chronic hepatitis $C$ infection (CHC) usually have immunological characteristics, such as circulating autoantibodies and deposits of immune complexes (ICs) in various tissues other than the liver, which may be an important pathogenic mechanism of extrahepatic disorders in the course of HCV infection (6). HCV also appears to be capable of directly infecting cells around the liver-a feature that may play an important role in determining some EHMs.

This hypothesis is supported by observations of HCV replication in extrahepatic tissues, such as bone marrow, the central nervous system, endocrine glands, lymph 
nodes, spleen, monocytes, macrophages, and skin cells. Moreover, there is some epidemiological evidence of relationship between chronic HCV infection and some of these EHMs (7-9). To date, the pathogenic mechanisms by which HCV acts as an instigator of B-cell lymphoproliferative disorders are not fully explained-the exact mechanisms by which B cells become dysregulated during the course of chronic HCV infection are not known. Difficulties in identifying disease mechanisms presumably stem from several issues, such as the wide heterogeneity of disease complications. Moreover, factors affecting the development of the disease may be related to the host, the virus, and the environment (10).The purpose of this study was to review the literature concerning the association between HCV infection, cryoglobulinemia, and NHL.

\section{Evidence Acquisition}

\subsection{Cryoglobulinemia}

Cryoglobulins are immunoglobulins (Igs) that precipitate in the cold and are classified into three groups, based on Ig clonality (11-14). Type I cryoglobulins are usually associated with lymphoproliferative disorders, including multiple myeloma and Waldenstrom macroglobulinemia, and usually consist of monoclonal Ig or a light chain. Type II cryoglobulins are composed of a polyclonal IgG and a monoclonal IgM RF reacting against the Fc portion of the IgG; it is identified as essential MC. It is believed that most of these essential MC are associated with CHC. Type III MC is also specified by RF activity, although polyclonal IgG and polyclonal IgM exist. There is a well-established link between type I cryoglobulinemia and well-known hematological diseases. This type of cryoglobulinemia is usually asymptomatic per se; similarly, circulating mixed cryoglobulins are commonly identified in a large number of infectious or systemic diseases (15). The first report indicating an association between HCV and cryoglobulinemia was published in 1990 (16). However, the number of cases of cryoglobulinemia associated with HCV reported annually has risen considerably. The incidence of $\mathrm{HCV}$ infection in MC ranges from $40 \%$ to $90 \%$ and varies geographically $(17,18)$. MC can be observed in up to $60 \%$ of HCV-infected patients, although nearly $5 \%$ to $20 \%$ of these patients develop overt cryoglobulinemic syndrome (19). This prominent association rate represents a causative link between HCV and MC (20).

However, HCV seems to play a prominent etiological role in the disease, especially in the Mediterranean area. Patients with HCV-negative MC are more frequently identified in the same areas where the overall prevalence of the disease is considerably low and where its relation with HCV is less common. These patients may represent true 'essential' MC $(17,21)$. Further evidence of an association between HCV infection and cryoglobulinemia has been provided by recent findings relating the presence of HCV RNA in the serum and/or peripheral mononuclear cells of patients with type II essential MC $(22,23)$. HCV antigens are detected within the ICs that precipitate in many organs, including the skin and kidneys of HCV-infected patients with MC-additional evidence in humans of a link between cryoglobulinemia and HCV infection (17).

\section{2. phatophysiology of HCV-Related Cryoglobulinemia}

HCV infection of peripheral lymphocytes suggests that this virus could be the stimulating factor for the lymphoproliferation that underlies MC. The mechanisms responsible for the clonal amplification of autoantibody-producing B cells and chronic lymphoproliferation in HCV infection remain controversial. Nonetheless, it has now become obvious that HCV has high tropism for peripheral lymphocytes, which may act as its reservoir and a site of replication (24). On B cells, CD81, which is part of a complex formed by CD21, CD19, and Leu13, lowers the threshold for B-cell activation. Flint et al. showed that HCV attaches to the CD81 ligand tetraspanin on the surface of B-lymphocytes through E2 protein (the second portion of the HCV envelope), resulting in activation of these lymphocytes (25). Thus, the CD81 molecule is an $\mathrm{HCV}$ receptor, and HCV infection of B cells is the possible cause of different disorders of B cell dysregulation, including MC and RF production (26).

It has also been shown that isolated intrahepatic $B$ lymphocytes are able to spontaneously secrete RFs that usually exhibit the WA crossreactive idiotype. The occurrence of oligoclonal or monoclonal patterns indicates that B cells derived from very few or single cells expand within the liver. It is also possible that initially, only polyclonal cryoglobulins are produced, after which a dominant B-cell clone emerges, synthesizing monoclonal Igs $(27,28)$. Therefore, expansion of autoantibodyproducing B-cells, due to dysregulation of anti-idiotype networks, may be one of the possible mechanisms for disease induction. Molecular mimicry represents another potential mechanism of B-lymphocyte activation and autoantibody production. For example, it seems that molecular mimicry between HCV antigens, such as NS5A and HCV core proteins and host autoantigens, triggers activation of B-lymphocytes and autoantibody production (29). Furthermore, the involvement of ICs has been suggested in the pathogenesis of disease. Various autoantibodies, including RF and cryoglobulins, are important in the formation of ICs (30). Moreover, the importance of the complement system must not be forgotten, because complement components that may be generated in the course of an infection are involved in the immune complex-mediated reactions. This system is highly activated in cryoglobulinemic patients (31), and efficient engagement of C1q protein by cryoglobulins may be the chief pathogenetic mechanism involved in the cryoglobulin-related pathway (32). There is no doubt that dysregulation of helper $\mathrm{T}$ cells and their cytokines aids in the production of autoantibodies, such as cryoglobulins. Nonetheless, there is some controversy concerning the pattern of cytokines in patients with HCV and cryo- 
globulinemia. On one hand, Atta et al. verified that HCV carriers with cryoglobulinemia have increased serum levels of IL-5, a Th2 cell-derived cytokine (33). Therefore, it is possible that $\mathrm{Th} 2$ responses that promote autoantibody production may responsible for the pathology of the disease. On the other hand, Saadoun et al. indicated that T cells from the liver of HCV-MC vasculitis patients display a significantly augmented liver Th1 profile compared to MC-negative controls (34). Therefore, further experiments are needed to clarify the role of Th1/Th2 cytokines in the pathogenesis of the disease. Genetic factors also appear to play a role in the disease (35). The high incidence of the disease among Mediterranean people and the association of certain human leukocyte antigen (HLA) specificities or alleles with disease have provided additional supports for this possibility. It seems that HLA type II polymorphisms, by interacting with T-cells, may influence the production of cryoglobulins $(36,37)$. In recent years, cryoglobulinemia has been a substantial focus, because it has become clear that cryoproteins may provoke signs and symptoms more often than previously identified. Mixed cryoglobulinemia symptoms (MCS) manifest in 10, 15\% to $30 \%$ of MC patients and in 5, $10 \%$ of all HCV-infected subjects (38). Due to the diverse clinical pictures, the presentation of MCS may significantly differ in various cases and in the same subject at various times. These clinical manifestations rely on the underlying disease; the dominant lesion of this disease is immune-mediated vasculitis. It may occur as a result of intravascular IC deposition in many organs, including skin, kidney, and peripheral nerves $(22,39,40)$. Other frequent symptoms of MCS are weakness, arthralgias, and palpable purpura that usually first develops in the lower extremities (41). Further signs may include Raynaud phenomenon, peripheral neuropathy, sicca syndrome, and membranoproliferative glomerulonephritis (MPGN), as well as lung disorders, fever, hematocytopenia, and diffuse vasculitis (42-44). The optimal therapeutic strategy for HCV-associated MC is based on both antiviral and limited immunosuppressive therapy with regard to activity and severity of the underlying vasculitis and the status of the underlying infection (45). IFN- $\alpha$ and ribavirin (RBV) are powerful antiviral drugs and can improve many of the clinical manifestations of MC, including skin vasculitis and renal disease (40). In spite of its remarkable therapeutic properties, IFN- $\alpha$ may have unwanted effects. For instance, Beuthien et al. introduced a case of a chronic HCV-infected patient who did not demonstrate signs of vasculitis or neuropathy before starting IFN therapy. This patient presented with cryoglobulinemic vasculitis with rigorous peripheral sensorimotor neuropathy following a virologic response that had been induced by antiviral treatment with pegylated interferon (PEG-IFN) and RBV (46). In addition, deterioration of vasculitis in patients with cryoglobulins without any new onset of vasculitis has been described (47). This observation has been confirmed by other studies (48). As a result, it is important for clinicians to be aware of these potentially severe side effects.

\subsection{Non-Hodgkin Lymphoma}

In 1958, Denis Burkitt recognized a new type of lymphoma in Uganda, which was named Burkitt lymphoma (49). In 1966, a classification of lymphoid neoplasms was proposed by Rappaport. He subsumed these cases under the term "NHL" (49). This disease is the most common cancer of the lymphatic system and is broadly divided into several subtypes, based on the predominant cell type of the tumor (50). The exact cause of NHL is unknown, but it appears that the disease is related to many risk factors, such as:

Certain conditions that can also weaken the immune system, such as acquired immunodeficiency syndrome, and immunosuppressive medications, particularly after transplants (50).

Exposure to certain viruses, such as Epstein-Barr virus, human T-lymphotropic virus type 1, human immunodeficiency virus, HCV, and certain bacteria, such as Helicobacter pylori $(50,51)$.

Family history of NHL-for example, having a sibling with the disease (though no hereditary pattern has been established) (52).

Exposure to chemicals, such as pesticides and solvents (53)

A possible association between $\mathrm{HCV}$ infection and B-cell NHL (B-NHL) was first reported in 1994 in Italy (54). The results of this study demonstrated a significant increase in the prevalence of HCV in a group of NHL patients (34\%) compared with controls (1\%). Subsequently, an association between HCV infection and B-NHL has also been noted by several epidemiological studies, indicating a high prevalence of HCV infection in B-NHL, ranging between $3.6 \%$ and $37 \%(55,56)$. Similarly, the high prevalence of HCV infection in patients with B lymphoma provides further support of the link between HCV infection and B-cell NHL (57). Additionally, there is a consistent association between HCV and MC. Chronic infection with HCV correlates with MC type II, which can progress into overt lymphoma in some patients (58). In light of these data, a strong relationship between NHL and HCV infection is implicated, which may be associated with extra-nodal involvement (especially salivary glands and liver), splenomegaly, lymphocytosis, cryoglobulins, cytolysis, and colestasis (59-61). The treatment strategy for HCV-associated NHL is similar to that of conventional lymphoma (62). Among these therapeutic methods, which may be implemented alone or in combination, immunotherapy is a newer approach. Several immunotherapeutic methods have been proposed in clinical trials, and studies have indicated that IFN treatment is generally well tolerated (63). With respect to NHL as an EHM of HCV infection, IFN- $\alpha$ appears to be an effective treatment $(63,64)$. The response to IFN therapy for chronic hepatitis $C$ has been improved tremendously with the use of RBV and PEG-IFN (63). However, some patients do not respond to this therapy, and several factors can contribute to unre- 
sponsiveness, including the characteristics of the virus, the subject who has been infected, and the therapy (63). In addition, IFN treatment has side effects. These unwanted effects can be divided into acute effects (such as fever, chill and rigors, headaches, myalgias, and malaise) that decline over time and those that are chronic (including fatigue, anorexia, neuropsychiatric symptoms) (65). Although antiviral therapy is an attractive therapeutic tool, a better understanding of the biology of IFN, its side effect profiles, and toxicity management will help to optimize its application in the treatment of HCV-related NHL patients.

\subsection{Pathophysiology of HCV-Related NHL}

The possibility of a pathogenic link between HCV and NHL has been strengthened by the finding of HCV antigens in tissues from patients with NHL (66), although the pathogenic mechanisms through which the virus induce clonal proliferation and transformation of B-cells are not known. A recent retrospective study has shown that HCV is associated with NHL, as well as other B cell lymphoproliferative disorders, such as Waldenström macroglobulinemia and monoclonal gammopathy of unknown significance (67). Moreover, despite evidence of the presence of HCV in malignant cells $(68,69)$, HCV viremia has been reported in up to $35 \%$ of patients with B cell lymphoma and nearly $90 \%$ of NHL patients with cryoglobulinemia (42). The data also indicate that extrahepatic manifestations of HCV infection, such as high serum levels of RF activity, cryoglobulins, monoclonal gammopathy of undetermined significance, and frank B-cell NHL, are virtually always associated with B-cell clonalities, which may have a direct impact on clinical features (70). Further evidence to support the hypothesis that HCV is directly involved in the emergence and maintenance of B-cell expansion has been provided by a demonstration of $\mathrm{HCV}$ enrichment in intrahepatic inflammatory infiltrates (35). This result is consistent with observations that HCV infects and may replicate in B cells (71-75) and lead to malignant transformation. However, this model can not describe the RF restriction that is seen in HCV MC, unless it is assumed HCV preferentially infects RF+B cells. Nonetheless, a B cell line that productively releases infectious HCV has been demonstrated (74), and several groups have detected a negative HCV strand, a viral replicative intermediate, associated with lymphocytes from HCV+ patients $(23,76,77)$. Alternatively, it has been proposed that specific HCV proteins are essential for clonal B cell expansion. This suggestion is strengthened by the following considerations:

-IgG Fc binding activity of HCV core (78), which could result in enhanced HCV-IC generation.

-Abrogation of p53-induced apoptosis by the NS5A protein of $\mathrm{HCV}$ (79)

-Elevated expression of activation-induced cytidine deaminase in CHC B cells after E2-CD81 interaction.

Cytidine deaminase is also expressed in B-NHL patients (80-82) and may be required for germinal center-derived lymphomagenesis (83). The E2-CD81 interaction could enhance the frequency of VDJ rearrangements in antigen-reactive B-cells (84-86), with possible Bcl-2 proto-oncogene activation $(84,85)$. Bcl-2 acts as an anti-apoptotic molecule, and its activation may be associated with the $\mathrm{t}(14 ; 18)$ chromosomal translocation. Interestingly, this translocation has been observed repeatedly in B-cells of HCV-infected individuals, particularly in those with type $\quad \mathrm{t} \mathrm{MC}(84,87)$, and could lead to abnormal B-cell survival (87). The extended survival of these highly selected B-cell clones may be related to the overexpression of genes (such as CCND1 and CCND2) in CHC B cells. This is an important finding, because enhanced expression of CCND, which changes cell cycle progression, has been frequently observed in different tumors and may participate in tumorigenesis $(88,89)$. Additionally, CCND2 is known to be expressed at constitutively high levels in B-NHL patients (90) and thus may be associated with Blymphomagenesis. Recent findings also suggest that $\mathrm{B}$ cell survival that occurs in HCV MC (91-94) may be related to the elevated levels of B cell-activating factor. This molecule is a member of the tumor necrosis factor family and may play a role in the survival of autoreactive B cells.

\section{Results}

Since cryoglobulin production is associated with B lymphocyte expansion, it is possible that B-cell NHL may contribute to complications of MC syndrome, usually after a long-lasting follow-up period (42). This occurrence, together with the remarkable association between MC and HCV infection, suggests a possible association between the same virus and 'idiopathic' B-cell NHL (56). The latter possibility is partly supported by data showing the similarities that are shared by rearranged Ig genes in B cells from patients with type II MC and malignant B-cells from HCV-positive patients with B-cell NHL $(95,96)$. Based on the facts and interpretations above, it should be noted that lymphomathogenesis is a complex and multistep process, in which HCV may act as an antigenic trigger in addition to other environmental and genetic factors. In other words, some investigators believe that one of the outcomes of long-term HCV infection is clonal B cell expansion of Ig (cryoglobulin)-secreting lymphocytes. This process, which can be regarded as one of the suspected environmental factors, in combination with genetic factors, may culminate in a mutational event, with activation of oncogenes, resulting in NHL.

\section{Conclusions}

HCV infection has been associated with numerous EHMs. The majority of HCV chronically infected patients has no hepatic symptoms and may have normal alanine transaminase. In other words, sometimes, the importance of EHM is more severe than the hepatic disease itself. Therefore, EHMs may be the reason that patients seek medical care and thus have a chance to be studied, identified, and finally suitably treated. Some of these EHMs, such as cryoglobulinemia and NHL, are thought 
to be the result of a HCV/B-cell interaction that possibly predisposes one to B-cell proliferation and clonal expansion. The antigenic dependence of these $B$ cells is demonstrated by evidence that HCV-related MC and NHL vanish after successful management of HCV infection. Whether B-cell clonal expansion of a particular specificity take places as a consequence of distinct selection is not obvious. The process of B-cell clonal expansion in a milieu that is favorable to the immortalization of one particular clone must be elucidated. Predisposing elements for transforming events must be recognized.

\section{Acknowledgements}

None declared.

\section{Authors' Contribution}

None declared.

\section{Financial Disclosure}

None declared.

\section{Funding/Support}

None declared.

\section{References}

1. Jadali Z, Alavian SM. Autoimmune diseases co-existing with hepatitis C virus infection. Iran J Allergy Asthma Immunol. 2010;9(4):191-206.

2. Jadali Z, Mansouri P, Jadali F. These is no relationship between hepatitis C virus and alopecia areata. Eur J Dermatol. 2006;16(1):94-5.

3. Jadali Z, Esfahanian F, Eslami MB, Sanati MH. Serum Antibodies against Hepatitis C Virus in Iranian Patients with Graves' Disease. Iran J Allergy Asthma Immunol. 2005;4(2):91-4.

4. Mizuochi T, Ito M, Saito K, Kasai M, Kunimura T, Morohoshi T, et al. Possible recruitment of peripheral blood CXCR3+ CD27+ CD19+ B cells to the liver of chronic hepatitis C patients. J Interferon Cytokine Res. 2010;30(4):243-52.

5. Charles ED, Dustin LB. Hepatitis C virus-induced cryoglobulinemia. Kidney Int. 2009;76(8):818-24.

6. Zarebska-Michaluk DA, Lebensztejn DM, Kryczka WM, Skiba E. Extrahepatic manifestations associated with chronic hepatitis $C$ infections in Poland. Adv Med Sci. 2010;55(1):67-73.

7. Manns MP, Rambusch EG. Autoimmunity and extrahepatic manifestations in hepatitis C virus infection.J Hepatol. 1999;31 (Suppl 1):39-42.

8. El-Serag HB, Hampel H, Yeh C, Rabeneck L. Extrahepatic manifestations of hepatitis C among United States male veterans. Hepatology. 2002;36(6):1439-45.

9. Zignego AL, Brechot C. Extrahepatic manifestations of HCV infection: facts and controversies. J Hepatol. 1999;31(2):369-76.

10. Conca P, Tarantino G. Hepatitis C virus lymphotropism and peculiar immunological phenotype: effects on natural history and antiviral therapy. World J Gastroenterol. 2009;15(19):2305-8.

11. Brouet JC, Clauvel JP, Danon F, Klein M, Seligmann M. Biologic and clinical significance of cryoglobulins. A report of 86 cases. Am J Med. 1974;57(5):775-88.

12. Gorevic PD, Kassab HJ, Levo Y, Kohn R, Meltzer M, Prose P, et al. Mixed cryoglobulinemia: clinical aspects and long-term followup of 40 patients. Am J Med.1980;69(2):287-308.

13. D'Amico G, Colasanti G, Ferrario F, Sinico RA. Renal involvement in essential mixed cryoglobulinemia. Kidney Int.1989;35(4):100414.

14. Trendelenburg M, Schifferli JA. Cryoglobulins are not essential. Ann Rheum Dis. 1998;57(1):3-5.
15. Ferri C. Mixed cryoglobulinemia. Orphanet J Rare Dis. 2008;3:25.

16. Ferri C, Greco F, Longombardo G, Palla P, Moretti A, Marzo E, et al. Association between hepatitis $C$ virus and mixed cryoglobulinemia [see comment]. Clin Exp Rheumatol.1991;9(6):621-4.

17. Sansonno D, Dammacco F. Hepatitis C virus, cryoglobulinaemia, and vasculitis: immune complex relations. Lancet Infect Dis. 2005;5(4):227-36.

18. Jadali Z. Dermatologic manifestations of hepatitis $C$ infection and the effect of interferon therapy: a literature review. Arch Iran Med. 2012;15(1):43-8.

19. Sansonno D, Carbone A, De Re V, Dammacco F. Hepatitis C virus infection, cryoglobulinaemia, and beyond. Rheumatology (OXford). 2007;46(4):572-8.

20. Agnello V. Hepatitis $C$ virus infection and type II cryoglobulinemia: an immunological perspective. Hepatology. 1997;26(6):13759.

21. Mascia MT, Ferrari D, Campioli D, Sandri G, Mussini C, Ferri C. Non HCV-related mixed cryoglobulinemia. Dig Liver Dis. 2007;39 (Suppl 1):S61-4.

22. Agnello V, Chung RT, Kaplan LM. A role for hepatitis C virus infection in type II cryoglobulinemia. N Engl J Med. 1992;327(21):14905.

23. Sansonno D, Lauletta G, Montrone M, Tucci FA, Nisi L, Dammacco F. Virological analysis and phenotypic characterization of peripheral blood lymphocytes of hepatitis C virus-infected patients with and without mixed cryoglobulinaemia. Clin Exp Immunol. 2006;143(2):288-96.

24. Ferri C, Monti M, La Civita L, Longombardo G, Greco F, Pasero G, et al. Infection of peripheral blood mononuclear cells by hepatitis C virus in mixed cryoglobulinemia. Blood.1993;82(12):3701-4.

25. Flint $\mathrm{M}$, McKeating JA. The role of the hepatitis $\mathrm{C}$ virus glycoproteins in infection. Rev Med Virol. 2000;10(2):101-17.

26. Ito M, Kusunoki H, Mochida K, Yamaguchi K, Mizuochi T. HCV infection and B-cell lymphomagenesis. Adv Hematol. 2011;2011:835314.

27. Dammacco F, Sansonno D, Piccoli C, Racanelli V, D’Amore FP, Lauletta $\mathrm{G}$. The lymphoid system in hepatitis $\mathrm{C}$ virus infection: autoimmunity, mixed cryoglobulinemia, and Overt B-cell malignancy. Semin Liver Dis. 2000;20(2):143-57.

28. Sansonno L, Tucci FA, Sansonno S, Lauletta G, Troiani L, Sansonno D. B cells and HCV: an infection model of autoimmunity. Autoimmun Rev. 2009;9(2):93-4.

29. Ferri C, Zignego AL, Pileri SA. Cryoglobulins. J Clin Pathol. 2002;55(1):4-13.

30. Antonelli A, Ferri C, Ferrari SM, Colaci M, Fallahi P. Immunopathogenesis of HCV-related endocrine manifestations in chronic hepatitis and mixed cryoglobulinemia. Autoimmun Rev. 2008;8(1):18-23.

31. Gorevic PD, Frangione B. Mixed cryoglobulinemia cross-reactive idiotypes: implications for the relationship of MC to rheumatic and lymphoproliferative diseases. Semin Hematol. 1991;28(2):7994.

32. Sansonno D, Tucci FA, Ghebrehiwet B, Lauletta G, Peerschke EI, Conteduca $\mathrm{V}$, et al. Role of the receptor for the globular domain of C1q protein in the pathogenesis of hepatitis C virus-related cryoglobulin vascular damage. JImmunol. 2009;183(9):6013-20.

33. Atta AM, Oliveira IS, Sousa GM, Parana R, Atta ML. Serum cytokine profile in hepatitis $\mathrm{C}$ virus carriers presenting cryoglobulinaemia and non-organ-specific autoantibodies. Microb Pathog. 2010;48(2):53-6.

34. Saadoun D, Boyer O, Trebeden-Negre H, Limal N, Bon-Durand V, Andreu M, et al. Predominance of type 1 (Th1) cytokine production in the liver of patients with HCV-associated mixed cryoglobulinemia vasculitis. J Hepatol. 2004;41(6):1031-7.

35. Gragnani L, Piluso A, Giannini C, Caini P, Fognani E, Monti M, et al. Genetic determinants in hepatitis $C$ virus-associated mixed cryoglobulinemia: role of polymorphic variants of BAFF promoter and Fcgamma receptors. Arthritis Rheum. 2011;63(5):144651.

36. De Re V, Caggiari L, Monti G, Libra M, Spina M, Dolcetti R, et al. HLA DR-DQ combination associated with the increased risk of developing human HCV positive non-Hodgkin's lymphoma is related to the type II mixed cryoglobulinemia. Tissue Antigens. 2010;75(2):127-35.

37. De Re V, Caggiari L, De Vita S, Mazzaro C, Lenzi M, Galli M, et al. 
Genetic insights into the disease mechanisms of type II mixed cryoglobulinemia induced by hepatitis C virus. Dig Liver Dis. 2007;39 (Suppl 1):S65-71.

38. Lunel F, Musset L, Cacoub P, Frangeul L, Cresta P, Perrin M, et al Cryoglobulinemia in chronic liver diseases: role of hepatitis $C$ virus and liver damage. Gastroenterology. 1994;106(5):1291-300.

39. Rebora A. Skin diseases associated with hepatitis $C$ virus: facts and controversies. Clin Dermatol. 2010;28(5):489-96.

40. Galossi A, Guarisco R, Bellis L, Puoti C. Extrahepatic manifestations of chronic HCV infection. J Gastrointestin Liver Dis. 2007;16(1):65-73.

41. Meltzer M, Franklin EC, Elias K, McCluskey RT, Cooper N. Cryoglobulinemia--a clinical and laboratory study. II. Cryoglobulins with rheumatoid factor activity. Am J Med.1966;40(6):837-56

42. Ferri C, Sebastiani M, Giuggioli D, Cazzato M, Longombardo G Antonelli A, et al. Mixed cryoglobulinemia: demographic, clini$\mathrm{cal}$, and serologic features and survival in 231 patients. Semin Arthritis Rheum. 2004;33(6):355-74.

43. Zignego AL, Giannini C, Ferri C. Hepatitis C virus-related lymphoproliferative disorders: an overview. World J Gastroenterol. 2007;13(17):2467-78.

44. Pipili C, Ilonidis G, Cholongitas E. Hepatitis C virus and kidney: a strong association with different clinical aspects. Liver Int. 2011;31(8):1071-80.

45. Saadoun D, Landau DA, Calabrese LH, Cacoub PP. Hepatitis Cassociated mixed cryoglobulinaemia: a crossroad between autoimmunity and lymphoproliferation. Rheumatology (Oxford). 2007;46(8):1234-42.

46. Beuthien W, Mellinghoff HU, Kempis J. Vasculitic complications of interferon-alpha treatment for chronic hepatitis $C$ virus infection: case report and review of the literature. Clin Rheumatol. 2005;24(5):507-15.

47. Batisse D, Karmochkine M, Jacquot C, Kazatchkine MD, Weiss L. Sustained exacerbation of cryoglobulinaemia-related vasculitis following treatment of hepatitis $\mathrm{C}$ with peginterferon alfa. Eur J Gastroenterol Hepatol. 2004;16(7):701-3.

48. Boonyapisit K, Katirji B. Severe exacerbation of hepatitis C-associated vasculitic neuropathy following treatment with interferon alpha: a case report and literature review. Muscle Nerve. 2002;25(6):909-13.

49. Jaffe ES, Harris NL, Stein H, Isaacson PG. Classification of lymphoid neoplasms: the microscope as a tool for disease discovery. Blood. 2008;112(12):4384-99.

50. Zagolski O, Dwivedi RC, Subramanian S, Kazi R. Non-Hodgkin's lymphoma of the sino-nasal tract in children.J Cancer Res Ther. 2010;6(1):5-10.

51. Marcucci F, Mele A. Hepatitis viruses and non-Hodgkin lymphoma: epidemiology, mechanisms of tumorigenesis, and therapeutic opportunities. Blood. 2011;117(6):1792-8.

52. Alexander DD, Mink PJ, Adami HO, Chang ET, Cole P, Mandel JS, et al. The non-Hodgkin lymphomas: a review of the epidemiologic literature. Int J Cancer. 2007;120 (Suppl 12):1-39.

53. Clapp RW, Jacobs MM, Loechler EL. Environmental and occupational causes of cancer: new evidence 2005-2007. Rev Environ Health. 2008;23(1):1-37.

54. Ferri C, Caracciolo F, Zignego AL, La Civita L, Monti M, Longombardo $G$, et al. Hepatitis $C$ virus infection in patients with nonHodgkin's lymphoma. Br J Haematol. 1994;88(2):392-4.

55. de Sanjose S, Benavente Y, Vajdic CM, Engels EA, Morton LM, Bracci PM, et al. Hepatitis C and non-Hodgkin lymphoma among 4784 cases and 6269 controls from the International Lymphoma Epidemiology Consortium. Clin Gastroenterol Hepatol. 2008;6(4):451-8

56. Vallisa D, Berte R, Rocca A, Civardi G, Giangregorio F, Ferrari B, et al. Association between hepatitis $C$ virus and non-Hodgkin's lymphoma, and effects of viral infection on histologic subtype and clinical course. Am J Med.1999;106(5):556-60.

57. Izumi T, Sasaki R, Miura Y, Okamoto H. B cell malignancy and hepatitis C virus infection. Leuk Res. 1996;20(5):445.

58. Zuckerman E, Zuckerman T. Hepatitis C and B-cell lymphoma: the hemato-hepatologist linkage. Blood Rev. 2002;16(2):119-25.

59. Vladareanu AM, Ciufu C, Neagu AM, Onisai M, Bumbea H, Vintilescu AM, et al. The impact of hepatitis viruses on chronic lymphoproliferative disorders--preliminary results. J Med Life.
2010;3(3):320-9.

60. Ascoli V, Lo Coco F, Artini M, Levrero M, Martelli M, Negro F. Extranodal lymphomas associated with hepatitis $C$ virus infection. Am J Clin Pathol.1998;109(5):600-9.

61. De Vita S, Sacco C, Sansonno D, Gloghini A, Dammacco F, Crovatto $\mathrm{M}$, et al. Characterization of overt B-cell lymphomas in patients with hepatitis C virus infection. Blood.1997;90(2):776-82.

62. Mazzaro C, Tirelli U, Pozzato G. Hepatitis C virus and non-Hodgkin's lymphoma 10 years later. Dig Liver Dis. 2005;37(4):219-26.

63. Masarone M, Persico M. Antiviral therapy: why does it fail in HCV-related chronic hepatitis? Expert Rev Anti Infect Ther. 2011;9(5):535-43.

64. Mazzaro C, De Re V, Spina M, Dal Maso L, Festini G, Comar C, et al. Pegylated-interferon plus ribavirin for HCV-positive indolent non-Hodgkin lymphomas. BrJ Haematol. 2009;145(2):255-7.

65. Jonasch E, Haluska FG. Interferon in oncological practice: review of interferon biology, clinical applications, and toxicities. Oncologist. 2001;6(1):34-55

66. Paydas S, Ergin M, Tanriverdi K, Yavuz S, Disel U, Kilic NB, et al. Detection of hepatitis $C$ virus RNA in paraffin-embedded tissues from patients with non-Hodgkin's lymphoma. Am J Hematol. 2004;76(3):252-7.

67. Giordano TP, Henderson L, Landgren O, Chiao EY, Kramer JR, El-Serag H, et al. Risk of non-Hodgkin lymphoma and lymphoproliferative precursor diseases in US veterans with hepatitis $C$ virus. JAMA. 2007;297(18):2010-7.

68. De Vita S, De Re V, Sansonno D, Gloghini A, Gasparotto D, Libra M, et al. Lack of HCV infection in malignant cells refutes the hypothesis of a direct transforming action of the virus in the pathogenesis of HCV-associated B-cell NHLs. Tumori. 2002;88(5):400-6.

69. Schollkopf C, Smedby KE, Hjalgrim H, Rostgaard K, Panum I, Vinner L, et al. Hepatitis C infection and risk of malignant lymphoma. Int J Cancer. 2008;122(8):1885-90.

70. Sansonno D, Lauletta G, De Re V, Tucci FA, Gatti P, Racanelli V, et al. Intrahepatic $B$ cell clonal expansions and extrahepatic manifestations of chronic HCV infection. Eur J Immunol. 2004;34(1):12636.

71. Pal S, Sullivan DG, Kim S, Lai KK, Kae J, Cotler SJ, et al. Productive replication of hepatitis $C$ virus in perihepatic lymph nodes in vivo: implications of HCV lymphotropism. Gastroenterology. 2006;130(4):1107-16

72. Pham TN, King D, Macparland SA, McGrath JS, Reddy SB, Bursey FR, et al. Hepatitis $C$ virus replicates in the same immune cell subsets in chronic hepatitis $\mathrm{C}$ and occult infection. Gastroenterology. 2008;134(3):812-22.

73. Stamataki Z, Shannon-Lowe C, Shaw J, Mutimer D, Rickinson $\mathrm{AB}$, Gordon J, et al. Hepatitis $\mathrm{C}$ virus association with periphera blood B lymphocytes potentiates viral infection of liver-derived hepatoma cells. Blood. 2009;113(3):585-93.

74. Sung VM, Shimodaira S, Doughty AL, Picchio GR, Can H, Yen TS et al. Establishment of B-cell lymphoma cell lines persistently infected with hepatitis $C$ virus in vivo and in vitro: the apoptotic effects of virus infection. J Virol. 2003;77(3):2134-46.

75. Ito M, Murakami K, Suzuki T, Mochida K, Suzuki M, Ikebuchi K, et al. Enhanced expression of lymphomagenesis-related genes in peripheral blood B cells of chronic hepatitis C patients. Clin Immunol. 2010;135(3):459-65.

76. Zignego AL, Ferri C, Giannini C, La Civita L, Careccia G, Longombardo $G$, et al. Hepatitis $C$ virus infection in mixed cryoglobulinemia and B-cell non-Hodgkin's lymphoma: evidence for a pathogenetic role. Arch Virol.1997;142(3):545-55.

77. Takyar ST, Li D, Wang Y, Trowbridge R, Gowans EJ. Specific detection of minus-strand hepatitis $C$ virus RNA by reverse-transcription polymerase chain reaction on PolyA(+)-purified RNA. Нераtology. 2000;32(2):382-7.

78. Maillard P, Lavergne JP, Siberil S, Faure G, Roohvand F, Petres S, et al. Fcgamma receptor-like activity of hepatitis $C$ virus core protein.J Biol Chem. 2004;279(4):2430-7.

79. Majumder M, Ghosh AK, Steele R, Ray R, Ray RB. Hepatitis C virus NS5A physically associates with p53 and regulates p21/wafi gene expression in a p53-dependent manner. JVirol. 2001;75(3):1401-7.

80. Greeve J, Philipsen A, Krause K, Klapper W, Heidorn K, Castle BE, et al. Expression of activation-induced cytidine deaminase in human B-cell non-Hodgkin lymphomas. Blood. 2003;101(9):3574- 
80

81. Pasqualucci L, Guglielmino R, Houldsworth J, Mohr J, Aoufouchi S, Polakiewicz R, et al. Expression of the AID protein in normal and neoplastic B cells. Blood. 2004;104(10):3318-25.

82. Smit LA, Bende RJ, Aten J, Guikema JE, Aarts WM, van Noesel CJ. Expression of activation-induced cytidine deaminase is confined to B-cell non-Hodgkin's lymphomas of germinal-center phenotype. Cancer Res. 2003;63(14):3894-8.

83. Pasqualucci L, Bhagat G, Jankovic M, Compagno M, Smith P, Muramatsu $\mathrm{M}$, et al. AID is required for germinal center-derived lymphomagenesis. Nat Genet. 2008;40(1):108-12.

84. Zignego AL, Ferri C, Pileri SA, Caini P, Bianchi FB. Extrahepatic manifestations of Hepatitis C Virus infection: a general overview and guidelines for a clinical approach. Dig Liver Dis. 2007;39(1):217.

85. Rosa D, Saletti G, De Gregorio E, Zorat F, Comar C, D'Oro U, et al. Activation of naive B lymphocytes via CD81, a pathogenetic mechanism for hepatitis $C$ virus-associated $B$ lymphocyte disorders. Proc Natl Acad Sci USA. 2005;102(51):18544-9.

86. Machida K, Cheng KT, Sung VM, Shimodaira S, Lindsay KL, Levine AM, et al. Hepatitis C virus induces a mutator phenotype: enhanced mutations of immunoglobulin and protooncogenes. Proc Natl Acad Sci U S A. 2004;101(12):4262-7.

87. Zignego AL, Ferri C, Giannelli F, Giannini C, Caini P, Monti M, et al. Prevalence of bcl-2 rearrangement in patients with hepatitis $\mathrm{C}$ virus-related mixed cryoglobulinemia with or without B-cell lymphomas. Ann Intern Med. 2002;137(7):571-80.

88. Fu M, Wang C, Li Z, Sakamaki T, Pestell RG. Minireview: Cyclin D1: normal and abnormal functions. Endocrinology. 2004;145(12):5439-47.

89. Nakamura S, Yatabe Y, Seto M. Cyclin D1 overexpression in malig- nant lymphomas, Pathol Int 1997;47(7):421-9.

90. Wessendorf S, Schwaenen C, Kohlhammer H, Kienle D, Wrobel G, Barth TF, et al. Hidden gene amplifications in aggressive B-cell non-Hodgkin lymphomas detected by microarray-based comparative genomic hybridization. Oncogene. 2003;22(9):1425-9.

91. Toubi E, Gordon S, Kessel A, Rosner I, Rozenbaum M, Shoenfeld $\mathrm{Y}$, et al. Elevated serum B-Lymphocyte activating factor (BAFF) in chronic hepatitis $C$ virus infection: association with autoimmunity. J Autoimmun. 2006;27(2):134-9.

92. Fabris M, Quartuccio L, Sacco S, De Marchi G, Pozzato G, Mazzaro C, et al. B-Lymphocyte stimulator (BLyS) up-regulation in mixed cryoglobulinaemia syndrome and hepatitis-C virus infection. Rheumatology (Oxford). 2007;46(1):37-43.

93. Sene D, Limal N, Ghillani-Dalbin P, Saadoun D, Piette JC, Cacoub P. Hepatitis $C$ virus-associated B-cell proliferation-the role of serum B lymphocyte stimulator (BLyS/BAFF). Rheumatology ( $O x$ ford). 2007;46(1):65-9.

94. Landau DA, Rosenzwajg M, Saadoun D, Klatzmann D, Cacoub P. The B lymphocyte stimulator receptor-ligand system in hepatitis C virus-induced B cell clonal disorders. Ann Rheum Dis. 2009;68(3):337-44.

95. De Vita S, Sansonno D, Dolcetti R, Ferraccioli G, Carbone A, Cornacchiulo $V$, et al. Hepatitis $C$ virus within a malignant lymphoma lesion in the course of type II mixed cryoglobulinemia. Blood.1995;86(5):1887-92.

96. Sansonno D, De Vita S, Cornacchiulo V, Carbone A, Boiocchi M, Dammacco F. Detection and distribution of hepatitis $C$ virusrelated proteins in lymph nodes of patients with type II mixed cryoglobulinemia and neoplastic or non-neoplastic lymphoproliferation. Blood.1996;88(12):4638-45. 